\title{
The Comparison of Two Versus More Than Two Tracts Percutaneous Nephrolithotomy for the Management of Staghorn Calculi
}

\author{
Staghorn Böbrek Taşlarının Yönetiminde İki ve İkiden Fazla Giriş \\ Perkütan Nefrolitotominin Karşılaştırılması
}

\section{(D) Yusuf Turushan Özcanll, (D) Mustafa Erkoç}

Beylikdüzü State Hospital, Clinic of Urology, İstanbul, Turkey

\section{Abstract}

Objective: In this study, we evaluated the outcomes of two tracts and more than two tracts for percutaneous nephrolithotomy (PCNL) performed in patients with staghorn calculus.

Method: We performed multi-tract PCNL on 132 patients with staghorn calculi, whose stone burdens varied between 7 and $28.2 \mathrm{~cm}^{2}$ in our clinics between March 2015 and August 2019. We compared the outcomes and complications of multi-tract PCNL in two groups of patients. Group 1 included patients with two percutaneous tracts, while the patients in group 2 had more than two percutaneous tracts. Stone surface areas and locations were preoperatively recorded. Intraoperative data included number of tracts, blood transfusion rates and operative times. Postoperative stone-free rates (SFR) were also investigated.

Results: Group 1 included 93 patients, while group 2 included 39. The mean stone burden (MBS) was $10.4 \mathrm{~cm}^{2}$ in group 1 and $11.3 \mathrm{~cm}^{2}$ in group 2, with no statistical difference. Blood transfusion rates were $22.5 \%$ (21/93) in group 1 and $46.1 \%(18 / 39)$ in group $2(p<0.05)$. The mean operative times were $135 \mathrm{~min}$ in group 1 and $168 \mathrm{~min}$ in group 2. SFR were $74.1 \%$ (69/93) and $74.3 \%$ (29/39), respectively, and there was no significant difference $(p=0.93)$. Major complications were recorded in 4 patients (3.4\%). In group 2, two patients had undergone angioembolization due to A- $V$ fistula, and intubated thoracostomy was performed on 1 patient due to the development of hydropneumothorax.

Conclusion: Our study has demonstrated that performing more than 2 tracts for complete clearance of stones does not significantly increase SFR. In addition, increasing number of tracts is associated with higher blood transfusion rates, prolonged operative times and enhanced complication rates.

Keywords: Multiple tracts, PCNL, staghorn stones

\section{Öz}

\begin{abstract}
Amaç: Bu çalışmadaki amacımız staghorn taşı olan hastalarda iki ve ikinin üzerinde giriş yapılan perkütan nefrolitotomi (PKNL) sonuçlarının ve komplikasyonlarının değerlendirilmesidir.
\end{abstract}

Yöntem: Kliniğimizde Mart 2015 ve Ağustos 2019 arası taş yükü 7 ve $28,2 \mathrm{~cm}^{2}$ arasında değişen staghorn kalkül nedeniyle multipl giriş yapılan 132 hasta çalışmaya dahil edildi. Hastalar iki gruba ayrılarak multipl giriş PKNL sonuçları ve komplikasyonları incelendi. Grup 1'de iki giriş yapılan hastalar incelenirken, grup 2'de ikiden fazla giriş yapılan hastalar incelendi. Taş yüzey alanları ve lokasyonları operasyon öncesi kayıt altına alındı. Giriş sayıları, kan transfüzyon oranları ve operasyon zamanları intraoperatif veriler olarak kaydedildi. Postoperatif taşsızlık oranı kayıt altına alındı.

Bulgular: Grup 193 hastayı içerirken grup 239 hastayı içermekteydi. Ortalama taş yükü grup 1'de 10,4 cm² iken grup 2'de 11,2 cm² idi, istatistiksel olarak anlamlı fark saptanmadı. Kan transfüzyon oranı grup 1'de \%22,5 (21/93) iken grup 2'de \%46,1 (18/39) olarak saptandı ( $p<0,05)$. Grup 1 için ortalama operasyon süresi 135 dakika iken grup 2 için 168 dakika olarak saptandı $(p<0,05)$. Taşsızlık oranı sırasıyla \%74,1 (69/93) ve 4,3 $(29 / 39)$ idi, iki grup arasında istatistiksel olarak anlamlı fark saptanmadı $(p=0,93)$. Sadece dört hastada majör komplikasyon gelişti $(\% 3,4)$. Grup 2'de iki hasta A-V fistül nedeniyle anjioembolizasyona gönderildi, bir hastaya da hidropnömotoraks nedeniyle torakostomi uygulandı.

Sonuç: Çalışmamız 2'den fazla girişin taşsızlık oranını anlamlı olarak yükseltmediğini ortaya koymuştur. Aynı zamanda giriş sayısı arttıkça kan transfüzyon oranı, operasyon süresinde uzama ve komplikasyon oranlarında artış gözlenmiştir.

Anahtar kelimeler: Multipl giriş, PKNL, staghorn böbrek taşı

Address for Correspondence: Mustafa Erkoç, Beylikdüzü State Hospital, Clinic of Urology, İstanbul, Turkey

E-mail: mustafa.erkoc@yahoo.com, drmustafaerkoc@gmail.com ORCID: orcid.org/0000-0003-0679-2873 Received: 09.09.2020 Accepted: 23.11.2020

Cite this article as: Özcanlı YT, Erkoç M. The Comparison of Two Versus More Than Two Tracts Percutaneous Nephrolithotomy for the Management of Staghorn Calculi. Bagcilar Med Bull 2021;6(1):37-41.

${ }^{\odot}$ Copyright 2021 by the Health Sciences University Turkey, Bagcilar Training and Research Hospital Bagcilar Medical Bulletin published by Galenos Publishing House. 


\section{Introduction}

Kidney stone is one of the most common diseases in daily urology practice. Thanks to the technological developments, PCNL, a minimally invasive method, is now preferred over open surgery for the management of kidney stones with its increased success and decreased complication rates. Nowadays, PCNL has taken its place as the first-line option for the management of large and multiple kidney stones, staghorn stones and lower calyceal calculi $(1,2)$.

Although several studies compared the outcomes of singleand multi-tract PCNL previously $(3,4)$, Chen et al. (5) reported that multi-tract PCNL assisted by EMS LithoClast master was safe and effective in achieving great stone clearance rate in one session, with acceptable morbidity for the treatment of staghorn calculi. In our study, we evaluated the outcomes of multi-tract PCNL of the management of staghorn calculi. The difference of our study from the others is the comparison of patients with two and more access tracts.

\section{Materials and Methods}

\section{Patients}

This retrospective study was carried out with the University of Health Sciences Turkey, Okmeydanı Training and Research Hospital Ethics Committee's approval dated 16.04.2019 and numbered 1,234. Informed consent form was obtained from all patients.

We compared the stone-free rates (SFR), morbidities and complications of 132 patients who underwent standard PCNL procedures for staghorn kidney stones in our clinics between March 2015 and June 2019 and who required multiple tracts at the same session. The comorbidities (hypertension, diabetes mellitus) of the patients were recorded. The patients were divided into 2 groups according to the number of tracts created to completely eliminate the stones (group 1 with 2 and group 2 with $>2$ access tracts). Two tracts were performed for 93 (70.4\%) cases, while more than two tracts were performed for 39 (29.6\%). The patients who underwent PCNL with more than two tracts were selected according to stone burden and stone location. Staghorn stones filling renal pelvis and extending to at least one calyx were defined as partial, and those filling renal pelvis and all calyces as complete staghorn stones. We included patients who underwent surgery due to kidney stones for the first time. Patients with solitary kidney and congenital kidney anomalies were excluded from the sample.

\section{Intervention methods}

Each patient was evaluated preoperatively with urine cultures, serum creatinine tests, urinary ultrasound, kidneyurinary bladder (KUB), intravenous pyelogram (IVP) and/ or non-contrast upper abdominal computed tomography (CT). Patients with preoperative urinary infection detected in antibiotic susceptibility tests were treated accordingly to avoid any perioperative emergence of potential bacteremia.

During the procedure, all patients underwent prophylactic antibiotherapy. An open-end ureteral catheter was inserted endoscopically in the lithotomy position to deliver contrast material into the kidney subject to PCNL procedure, and to prevent the inadvertent escape of small stone fragments into the ureter during lithotripsy. After the patient was placed in the prone position and the kidney was fully outlined with the contrast material under fluoroscopic guidance, an 18-gauge needle was inserted through skin using the bull's eye technique. A co-axial dilator and a carrier sheath were placed over a guide wire previously inserted. The tract was dilated with a balloon catheter, inflated to $14 \mathrm{AP}$ and threaded over a carrier catheter. Intracorporeal lithotripsy was achieved using an ultrasonographic (Storz) and/or pneumatic lithotripter (El-Med). The procedure was performed for the other calyx or calices in the same manner and terminated after the placement of a $14 \mathrm{~F}$ Malecot nephrostomy tube. If an additional nephrostomy tube was suspected to be insufficient for complete drainage or bleeding in other tracts, these tracts were also intubated. After obtaining a nephrostogram, tubes were withdrawn during the postoperative period (Figure 1).

\section{Measured Outcomes}

Stone burden was calculated with preoperative KUB and non-contrast CT for non-opaque stones. In calculating
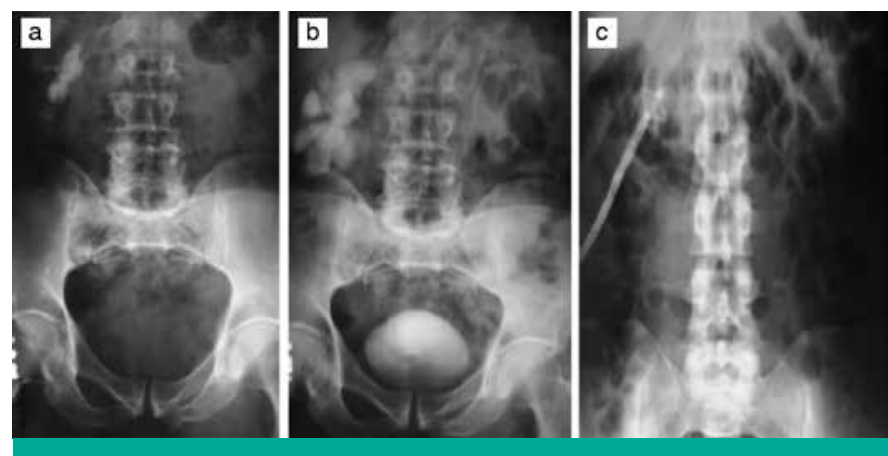

Figure 1. a) Kidney-urinary bladder X-ray b) Preoperative intravenous pyelogram c) Postoperative KUB X-ray of the staghorn stone

KUB: Kidney-urinary bladder 
the stone burden, the largest length and largest width of the stone were used. Postoperative hemoglobin ( $\mathrm{Hb})$ loss, blood transfusion rates, complication rates, duration of operation and SFR were recorded in both groups. The patients were monitored at the $1^{\text {st }}$ and $3^{\text {rd }}$ months with KUB and non-contrast CT for non-opaque stones, hemogram, measurements of BUN, creatinine, and urinalysis. Stone free rate was measured by KUB or non-contrast CT at the postoperative $3^{\text {rd }}$ month.

\section{Statistical Analysis}

Statistical analyses were performed using the Fisher's Exact test, chi-squared test and independent t-test for independent factors. $\mathrm{p}<0.05$ was considered as statistically significant.

\section{Results}

One hundred thirty two renal units in 132 patients aged between 21 and 66 years (median age: 34.5 years) underwent standard PCNL in our clinics due to the presence of staghorn calculi (Table 1). There were 33 females and 99 males, with 36 complete and 96 partial staghorn stones removed. In total, 318 tracts were created to eliminate the stones from 132 renal units. Two- 4 tracts were constructed for each renal unit. Two ( $\mathrm{n}=93 \mathrm{pts}), 3$ ( $\mathrm{n}=24 \mathrm{pts})$ and 4 ( $\mathrm{n}=15 \mathrm{pts})$ access tracts were constructed. The mean preoperative $\mathrm{Hb}$ value was $14.18 \mathrm{~g} / \mathrm{dL}$ (10.6$17.2 \mathrm{~g} / \mathrm{dL}$ ) (Table 1). The mean preoperative serum creatinine value was $0.96 \mathrm{mg} / \mathrm{dL}$ (0.51-3.36 mg/dL) (Table 1). The mean postoperative drop in Hb levels was $2.4 \mathrm{~g} /$ dL (1-7.2 g/dL). Blood transfusion was required for 26 (29.5\%) patients. Rates of blood transfusion were $22.5 \%$ $(14 / 62)$ and $46.1 \%(18 / 39)$ in groups with 2 and more than 2 tracts, respectively. When evaluated for the rate of blood transfusions, the incidence of bleeding was statistically significantly higher in group $2(\mathrm{p}<0.05)$.

\section{Table 1. Patients' demographic data}

\begin{tabular}{ll} 
Age, (years) & $34.5(21-66)$ \\
Female/male ratio & $1: 3$ \\
Hypertension & $32(24 \%)$ \\
Diabetes mellitus & $30(22.7 \%)$ \\
Preoperative mean Hb (g/dL) & $14.18 \mathrm{~g} / \mathrm{dL}(10.6-17.2 \mathrm{~g} / \mathrm{dL})$ \\
Preoperative mean creatinine & $0.96 \mathrm{mg} / \mathrm{dL}(0.51-3.36 \mathrm{mg} / \mathrm{dL})$ \\
value & \\
Drop in Hb & $2.4 \mathrm{~g} / \mathrm{dL}(1.4-7.2)$ \\
Duration of nephrostomy & $2.42(2-6)$ days \\
Time to discharge & $5.2(4-14)$ days \\
\hline
\end{tabular}

Hb: Hemoglobin
Our mean SFR was 64.7. SFR achieved at one session was $74.1 \%(69 / 93)$ in group 1 and $74.3 \%$ in group 2 (29/39). No statistically significant difference was seen between the two groups ( $\mathrm{p}=0.93)$.

The MBS was $10.4 \mathrm{~cm}^{2}\left(7-25 \mathrm{~cm}^{2}\right)$ in group 1 and 11.3 $\mathrm{cm}^{2}\left(7.5-28.2 \mathrm{~cm}^{2}\right)$ in group 2. Stone burdens were similar between the groups $(\mathrm{p}=0.88)$. The mean operation times were $135 \mathrm{~min}$ in group 1 and $168 \mathrm{~min}$ in group 2 , and these results were statistically significant $(\mathrm{p}<0.05)$.

In all patients, major complications were seen only in 4 (3.4\%) (Table 2). In group 2, 3 patients had undergone angioembolization due to $\mathrm{A}-\mathrm{V}$ fistula, and intubated thoracostomy was performed on 1 patient due to the development of hydropneumothorax. A $26 \mathrm{~cm}$ - long $4.8 \mathrm{~F}$ double J (DJ) ureteral catheter was placed in patients with residual stones of $>0.7 \mathrm{~cm}$ detected on KUBs obtained on the postoperative $1^{\text {st }}$ month, and they were then transferred to an Extracorporeal Shock Wave Lithotripsy (ESWL) unit. Ureterorenoscopy was performed and a DJ catheter was inserted in 3 patients due to the presence of ureteral stones. Nephrostomy tube was withdrawn in an average of 2.42 days after obtaining an antegrade renogram. The mean hospital stay was 5.2 days (4-14 days) (Table 1 ).

\section{Discussion}

Currently, PCNL is an increasingly prevalent treatment method with convenient long-term effectiveness and complication rates in the management of staghorn kidney stones. In a prospective, randomized study on 79 patients with staghorn calculi, where PCNL and open surgery were compared, PCNL blood loss, infection rates and hospital stay were found to be decreased, while SFR was similar (6). In two separate studies performed with the same aim, blood loss was stated to be less in PCNL compared to open surgery (7). In a retrospective study on

Table 2. Stone characteristics and postoperative outcomes

\begin{tabular}{llll} 
& $\begin{array}{l}\text { 2 tracts } \\
\text { (93 patients) }\end{array}$ & $\begin{array}{l}\text { >2 tracts } \\
\text { (39 patients) }\end{array}$ & p \\
\hline $\begin{array}{l}\text { Mean stone } \\
\text { burden }\end{array}$ & $10.4 \mathrm{~cm}^{2}$ & $11.3 \mathrm{~cm}^{2}$ & $\mathrm{p}=0.88$ \\
$\begin{array}{l}\left(7-25 \mathrm{~cm}^{2}\right) \\
\text { Stone free rate }\end{array}$ & $\begin{array}{l}74.1 \% \\
(69 / 93)\end{array}$ & $\begin{array}{l}74.3 \% \\
(29 / 39)\end{array}$ & $\mathrm{p}=0.93$ \\
& $21 / 93$ & $18 / 39$ & \\
$\begin{array}{l}\text { Blood } \\
\text { transfusion rate }\end{array}$ & $(22.5 \%)$ & $(46.1 \%)$ & $\mathrm{p}<0.05$ \\
$\begin{array}{l}\text { Duration of } \\
\text { operation (mins) }\end{array}$ & $135 \mathrm{mins}$ & $168 \mathrm{mins}$ & $\mathrm{p}<0.05$ \\
$\begin{array}{l}\text { Major } \\
\text { complication }\end{array}$ & None & $3 \mathrm{~A}-\mathrm{V}$ fistula & \\
\hline
\end{tabular}


119 patients with staghorn calculi managed with PCNL, postoperative SFR was reported to be $80 \%, 87.5 \%$ and $84.8 \%$ based on the location and type of the staghorn stone. Multiple tracts were created on 33 patients (27.7\%), and a seriously higher requirement for transfusion was noticeable $(8,9)$. Winfield et al. (10) intended to send their patients home with minimal number of residual stone particles using multi-tract PCNL (up to 4 tracts) and other assisted management modalities in multiple sessions (up to 5). They reported an $86 \%$ SFR within the first 6 months.

In a study where factors affecting blood loss after PCNL were investigated on 301 patients, $7.9 \%$ of the patients received blood transfusions, and diabetes, multiple tracts and prolonged operation time were indicated as factors increasing blood loss (11). In a study where factors effecting renal bleeding were investigated, the presence of staghorn calculi and multiple tracts were found to be among the most important etiologic factors (12). In a study investigating safety and the efficacy of multiple tracts in the presence of the staghorn stones in 149 patients, SFR and blood transfusion rates in one PCNL session were found to be $70.7 \%$ and $30.8 \%$, respectively (13).

Thanks to its lesser morbidity along with SFR similar to those of open surgery, PCNL has become a valuable technique for the management of staghorn stones. It must not be forgotten that many authors have recommended the application of minimally invasive surgical principles (14). In studies performed, dimercaptosuccinic acid scanning (15) or IVP (16) demonstrated that endourological interventions did not affect postoperative renal function. PCNL is a prominently valuable intervention in the management of staghorn kidney stones. In staghorn calculi, the success of PCNL depends on the achievement of an optimal renal access. PCNL is highly effective when performed through a single tract, and it should not be forgotten that multiple tracts might result in increased blood loss, as shown in our study.

In our study, SFR was not different between the groups with 2 or more than 2 tracts, having nearly equal MBS. Inability to detect any statistically significant difference in SFR in the 2 groups with similar stone burdens led us to think that different calyceal locations of stones, rather than the stone burden, are a relatively more important factor in achieving improved SFR.

Besides, with increased number of tracts, increased blood transfusion rates, operation times and complications were noted. As in other studies, the number of tracts was determined as the most important factor influencing blood transfusion rates $(8,9,11)$.

In a study where more than 1,000 cases were investigated for complications of PCNL, the incidence of major complications was found to be between 0.9 and 4.7 percent (17). In our study, major complication rate $(3.4 \%)$ was similar to that of the mentioned study in the literature.

Our SFR rates achieved in one session were $74.1 \%$ in group 1 and $74.3 \%$ in group 2 , which were lower than those found in other studies. In the recently updated American Urological Association Nephrolithiasis Guidelines panel on the Management of Staghorn Calculi, a mean SFR of $78 \%$ was established after PCNL monotherapy (1). Latest advances in instrumentation and technology have improved SFR, enhanced therapeutic effectiveness and decreased morbidity. Widespread use of flexible nephroscopy, and laser lithotripsy has lessened the number of tracts required for the management of staghorn calculi. Wong and Leveille used a rigid nephroscope for percutaneous access together with a flexible nephroscope and holmium: YAG laser lithotriptor through a single percutaneous access site for the management of 45 patients with partial or complex staghorn stones (18). They achieved a $95 \%$ SFR using an average of 1.6 procedures for each patient. Still, in our study, blood transfusion rates were found to be $22.5 \%$ in group 1 and $46.1 \%$ in group 2 , which were higher than those reported in other trials. In the American Urological Association Nephrolithiasis Guidelines panel on the Management of Staghorn Calculi, a 14-24\% blood transfusion rate was given for PCNL monotherapy (1).

The unavailability of flexible nephropscope and holmium YAG laser lithotripter in our clinics was in our opinion the most important reason for our lower SFR and higher blood transfusion rates compared to those mentioned in the literature. However, when we comparatively evaluated our patients with each other, we could not observe any superiority in regards to creating more than two tracts over 2 tracts in terms of SFR.

We believe that there is a need for further studies comparing the results of previous PCNLs and those performed using a flexible nephroscope and holmium YAG laser lithotripter in order to obtain more satisfactory outcomes.

\section{Study Limitations}

There were various limitations of our study, as it was a retrospective study with the limited number of patients. In addition, floroscopy time and postoperative pain score were not recorded in many patients, so these parameters 
were not included in the study. If these parameters had been added, the article would have been better.

\section{Conclusion}

Although PCNL is the first-line alternative in the management of staghorn calculi aiming complete clearance of calculi, using more than 2 racts in PCNL does not achieve a significant increase in SFR. Besides, increasing the number of tracts is associated with higher blood transfusion rates, longer operation times and numerous other complications. In our opinion, it is crucial to achieve desirable stone-free rates using a minimal number of properly-placed tracts under the guidance of suitable and sophisticated technical equipment. This is an important factor preventing the patient from the burden of unnecessary morbidity.

\section{Acknowledgement}

No research support or funding was received in connection with this study. The authors have no significant affiliation or involvement, either direct or indirect, with any organization or entity with a direct financial interest in the subject matter or materials discussed.

\section{Ethics}

Ethics Committee Approval: This study was carried out with the University of Health Sciences Turkey, Okmeydanı Training and Research Hospital Ethics Committee's approval dated 16.04.2019 and numbered 1,234.

Informed Consent: Informed consent form was obtained from all patients.

Peer-review: Externally peer-reviewed.

\section{Authorship Contributions}

Concept: M.E., Y.T.Ö., Design: M.E., Y.T.Ö., Data Collection or Processing: M.E., Y.T.Ö., Analysis or Interpretation: M.E., Literature Search: M.E., Writing: M.E.

Conflict of Interest: No conflict of interest was declared by the authors.

Financial Disclosure: The authors declared that this study has received no financial support.

\section{References}

1. Preminger GM, Assimos DG, Lingeman JE, Nakada SY, Pearle MS, Wolf JS Jr. AUA Nephrolithiazis Guideline on management of staghorn calculi: diagnosis and treatment recommendations. J Urol 2005;173(6):1991-2000.
2. Kaya E, Ebiloğlu T, Zor M, Yalçın S, Coğuplugil AE, Bedir S. The outcome of percutaneous nephrolithotomy on $\geq 50 \mathrm{~mm}$ staghorn and multiple calyceal stones. Turk J Urol 2018;44(2):148-152.

3. Besiroglu H, Merder E, Dedekarginoglu G. Percutaneous nephrolithotomy is safe and effective in aging male patients: a single center experience. The Aging Male 2019:1-6.

4. Zhao Z, Cui Z, Zeng T, Zhao Z, Cui Z, Zeng T. Comparison of 1-stage with 2-stage Multiple-tracts Mini-percutaneous Nephrolithotomy for the Treatment of Staghorn Stones: A Matched Cohorts Analysis. Urology 2016;87(1):46-51.

5. Chen J, Zhou X, Chen Z. Multiple tracts percutaneous nephrolithotomy assisted by Litho Clast master in one session for staghorn calculi: report of 117 cases. Urolithiasis 2014;42(2):165169 .

6. Khaled M, Kohlany AL, Ahmed A, Mohsen T, Shoma AM, Eraky I, et al. Treatment of complete staghorn stones: a prospective randomized comparison of open surgery versus percutaneous nephrolithotomy. J Urol 2005;173(2):469-473.

7. Snyder JA, Smith AD. Staghorn calculi. Percutaneous extraction versus anatrophic nephrolithotomy. J Urol 1986;136(2):351.

8. Kahnoski RJ, Lingeman JA, Coury TA, Steele RE, Mosbaugh PG. Combined percutaneous and extracorporeal shock wave lithotripsy for staghorn calculi: an alternative to anatrophic nephrolithotomy. J Urol 1986;135(4):679-681.

9. Netto NR, Ikonomidis J, Ikari O, Claro JA. Comparative study of percutaneous access for staghorn calculi. Urology 2005;65(4):659662 .

10. Winfield HN, Clayman RV, Chaussy CG, Weyman PJ, Fuchs GJ, Lupu AN. Monotherapy of staghorn renal calculi: a comparative study between percutaneous nephro-lithotomy and extracorporeal shock wave lithotripsy. J Urol 1998;139(5):895-899.

11. Kukreja R, Desai M, Patel S, Bapat S, Desai M. Factors affecting blood loss during percutaneous nephrolithotomy: prospective study. Endourol 2004;18(8):715-722.

12. Turna B, Nazli O, Demiryoguran S, Mammadov R, Cal C. Percutaneous Nephrolithotomy: Variables That Influence Hemorrhage. Adult Urology 2007;69(4):603-607.

13. Singia M, Srivastata A, Kapoor R, Gupta N, Ansari MS, Dubey D, et al. Agressive Approach to Staghorn Calculi-Safety and Efficacy of Multiple Tracts Percutanneous Neprolithotomy. Urology 2008;71(6):10039-11042.

14. Eisenberger F, Rassweiler J, Bup P, Kallert B, Miller K. Differentiated approach to staghorn calculi using extracorporeal shock wave lithotripsy and percutaneous nephrolithotomy: an analysis of 151 consecutive cases. World J Urol 1987;5:248-254.

15. Morey AF, Nitahara KS, McAninch JW. Modified anatrophic nephrolithotomy for management of staghorn calculi: is renal function preserved. J Urol 1999;162(3 Pt 1):670-673.

16. Tasca A, D'Angelo A, Zattoni F, Ferrarese P, Calo L, Bui F, et al. Shortterm and stabilized effects of percutaneous nephrolithotomy on the kidney. Eur Urol 1988;14(2):120-122.

17. Michel MS, Trojan T, Rasweiler J. Complications in Percutaneus Nephrolithotomy. Eur Urol 2007;51(4):899-906.

18. Wong C, Leveille RJ. Single upper-pole percuteneous access for treatment of $5 \mathrm{~cm}$ complex branched staghorn calculi: is shockwave lithotripsy necessary? J Endourol 2002;16(7):477-481. 